\title{
Mutations in dock1 disrupt early Schwann cell development
}

Rebecca L. Cunningham', Amy L. Herbert ${ }^{1}$, Breanne L. Harty ${ }^{1,2}$, Sarah D. Ackerman ${ }^{1,3}$ and Kelly R. Monk ${ }^{1,2^{*}}$

\begin{abstract}
Background: In the peripheral nervous system (PNS), specialized glial cells called Schwann cells produce myelin, a lipid-rich insulating sheath that surrounds axons and promotes rapid action potential propagation. During development, Schwann cells must undergo extensive cytoskeletal rearrangements in order to become mature, myelinating Schwann cells. The intracellular mechanisms that drive Schwann cell development, myelination, and accompanying cell shape changes are poorly understood.

Methods: Through a forward genetic screen in zebrafish, we identified a mutation in the atypical guanine nucleotide exchange factor, dock1, that results in decreased myelination of peripheral axons. Rescue experiments and complementation tests with newly engineered alleles confirmed that mutations in dock1 cause defects in myelination of the PNS. Whole mount in situ hybridization, transmission electron microscopy, and live imaging were used to fully define mutant phenotypes.

Results: We show that Schwann cells in dock1 mutants can appropriately migrate and are not decreased in number, but exhibit delayed radial sorting and decreased myelination during early stages of development.

Conclusions: Together, our results demonstrate that mutations in dock1 result in defects in Schwann cell development and myelination. Specifically, loss of dock1 delays radial sorting and myelination of peripheral axons in zebrafish.
\end{abstract}

Keywords: dock1, Schwann cell development, Myelination, Zebrafish

\section{Background}

Myelin, a lipid-rich multi-membrane structure, is an innovation of jawed vertebrates that enables the efficient conduction of action potentials. Schwann cells are the myelinating glia of the peripheral nervous system (PNS), and one Schwann cell myelinates one axonal segment. Schwann cells are derived from the neural crest and undergo a distinct series of developmental stages $[1,2]$. These developmental stages of Schwann cells require migration as well as unique and substantial changes in cell shape. Schwann cell precursors (SCPs) migrate great distances longitudinally down peripheral nerves. SCPs develop into immature Schwann cells, which undergo a unique process called radial sorting in which Schwann cells extend processes into axon bundles and select an

\footnotetext{
* Correspondence: monk@ohsu.edu

${ }^{1}$ Department of Developmental Biology, Washington University School of Medicine, St. Louis, MO 63110, USA

${ }^{2}$ Vollum Institute, Oregon Health and Science University, Portland, OR 97239, USA

Full list of author information is available at the end of the article
}

axon to myelinate [3]. Prior to myelination, Schwann cells wrap themselves 1-1.5 times around a selected axon segment in what is termed the pro-myelinating state. A mature Schwann cell extends and wraps its membrane to form a myelin sheath around an axonal segment. Cytoskeletal dynamics are needed to facilitate these different stages of Schwann cell development and extensive changes in cell shape, but the intracellular intermediates between extracellular signals and the remodeling of the Schwann cell cytoskeleton are not well defined.

The Rho-GTPase Rac1 is well known for its role in facilitating cell shape changes through regulating polymerization of the actin cytoskeleton and mediates Schwann cell development [4]. In Schwann cells, differential levels of Rac1 direct when a Schwann cell stops migrating and begins radial sorting and myelination [5]. Schwann cell-specific ablation of Rac1 in a mouse model causes delays in radial sorting and myelination, as well as aberrant Schwann cell process extension [5-7].

(c) The Author(s). 2018 Open Access This article is distributed under the terms of the Creative Commons Attribution 4.0 International License (http://creativecommons.org/licenses/by/4.0/), which permits unrestricted use, distribution, and 
Furthermore, Rac1 can function downstream of $\beta 1$-integrin in Schwann cells performing radial sorting [5]; however, the intracellular mechanisms that influence the temporal and spatial activation of Rac1 following extracellular signaling during Schwann cell development are not well understood.

Guanine nucleotide exchange factors (GEFs) have the ability to temporally and spatially regulate the activation of RhoGTPases, such as Rac1, because many GEFs can regulate the same RhoGTPase [8]. Roles of specific GEFs during distinct stages of Schwann cell development are beginning to be understood and help to broaden our knowledge of how extracellular signals are translated to intracellular signals in order to facilitate alterations in Schwann cell shape and movement [9-12]. In addition to canonical GEFs, atypical GEFs also have the ability to activate RhoGTPases. One such family of atypical GEFs, the Dock1-related GEFs, is composed of 11 family members, including Dock1 (also known as Dock180). Dock1 is highly evolutionarily conserved across species and can specifically bind and activate Rac1 [13-15]. In vitro and in vivo studies in various model organisms have shown that Dock1 influences a variety of cytoskeletal-related cell processes such as phagocytosis and cell migration [16-19]. Thus, Dock1 represents an ideal intracellular candidate to study for a role in cell shape regulation.

Although Dock1 has been studied in several biological contexts and is expressed in Schwann cells [20], a role for Dock1 has not yet been described in Schwann cell myelination. The ability of Dock1 to initiate changes in cell shape to facilitate phagocytosis and cell migration makes Dock1 an attractive candidate to investigate for a role in regulated cell shape changes throughout the development of Schwann cells, particularly during stages of radial sorting and myelination, when Rac1 levels most influence Schwann cell biology [4]. Two other members of the Dock1 family, Dock7, which activates the RhoGTPase Cdc42 [20], and Dock8 [21], which can activate Cdc42 and Rac1, have been shown to influence SCP migration through in vitro and in vivo knockdown experiments. Therefore, other members of the Dock1 family may also be key intracellular signals regulating the timing of Schwann cell development.

In this study, we utilized zebrafish to study Schwann cell myelination [22], and we identify and characterize Dock1 as a regulator of early Schwann cell myelination. Although previous morpholino experiments in zebrafish have implicated dock1 in myoblast development and vasculature morphogenesis [23-25], a role for Dock1 in Schwann cell development has not been examined. In a screen for genetic regulators of myelination, we identified an early stop codon in dock1 that causes decreased expression of a mature myelin marker, myelin basic protein $(m b p)$, in the PNS. Transmission electron microscopy (TEM) revealed that fewer axons are myelinated in mutants during early stages of myelin development, while axon number is not affected. We determined that SCP cell number and migration is not affected in dock1 mutants. Instead, radial sorting is delayed and early markers of myelination are reduced. These data suggest that Dock1 may contribute to the timely process extension of Schwann cells required for radial sorting and myelination.

\section{Methods and materials}

\section{Zebrafish lines and rearing conditions}

Zebrafish were reared in accordance with the Washington University IRB and animal protocols and were raised in the Washington University Zebrafish Consortium (http://zebrafish.wustl.edu/husbandry.htm). Zebrafish were crossed as either pairs or harems, and embryos were subsequently raised at $28.5{ }^{\circ} \mathrm{C}$ in egg water $(5 \mathrm{mM} \mathrm{NaCl}, 0.17 \mathrm{mM} \mathrm{KCl}$, $0.33 \mathrm{mM} \mathrm{CaCl} 2,0.33 \mathrm{mM} \mathrm{MgSO}_{4}$ ). Larvae were staged at hours post fertilization (hpf) and days post fertilization (dpf). The following mutant and transgenic strains were utilized in this study: $\operatorname{dock} 1^{\text {stl } 145}$, dock $1^{\text {stl } 365}$, dock $1^{\text {stl366 }}$, $\operatorname{Tg}(\operatorname{sox} 10(4.9):$ :nls-eos) [26], $\operatorname{Tg}($ foxd3:gfp) [27], and $\mathrm{Tg}\left(\mathrm{kdlr}\right.$ :mcherry) [28]. Homozygous dock ${ }^{\text {stll45 }}$ fish are viable as adults, therefore maternal zygotic (MZ) dock $1^{\text {stlins }}$ animals were generated by crossing a dock $k^{\text {tll145/stll45 }}$ female with a $\operatorname{dock} 1^{\text {stll45/+ }}$ male.

\section{Genotyping}

To identify adult and larval zebrafish for either rearing or phenotypic analyses, the following primers were used to amplify a region of interest by PCR: stl145 F: 5'-CATA GGCGTTCTTCACTGAG-3' and R: 5'CGTATTTCC CACTAAACAGC-3', stl365 F: 5'-GCAGCCACTTTAAA GCTTCCCG-3' and R: 5'-GCTGCTTACCTTGCCCT TGTC-3', and stl366 F: 5'-CCAGTGCCTCACTTCATAT CTCC-3' and R: 5' CTCTTAGTCTCACGCAACACT CATG-3'. After PCR, a restriction enzyme digest assay was performed and the resulting fragments were analyzed on a 3\% agarose gel. The stl145 C-to-T mutation disrupts a BstNI site so that the wild-type PCR product is cleaved into 48 and 527 base pair (bp) products, and the mutant PCR product is $575 \mathrm{bp}$. The stl365 allele contains a one bp insertion that disrupts an EcoRV binding site so that the wild-type PCR product is cleaved into 86 and $159 \mathrm{bp}$ products, and the mutant PCR product is $245 \mathrm{bp}$. The stl366 allele contains a 13-bp deletion that disrupts a HpyCH4III site so that the wild-type PCR product is cleaved into $323 \mathrm{bp}$ and $165 \mathrm{bp}$ products, and the mutant PCR product is $488 \mathrm{bp}$.

\section{Zebrafish mutant strain generation}

$\operatorname{dock} 1^{\text {stll45 }}$ was identified in a forward genetic screen described previously in $[29,30]$. Phenotypically wild-type and mutant $5 \mathrm{dpf}$ larvae were pooled and extracted DNA was sent for whole genome sequencing at the 
Genome Technology Access Center (GTAC) at Washington University. The wild-type to mutant allele ratio was determined using a bioinformatics pipeline generated in-house, and a SNP subtraction analysis suggested that dock1 was most likely the gene of interest [30]. dock 1 was confirmed as the gene responsible for the stl145 mutant phenotype through rescue experiments and complementation tests using two other dock1 mutant alleles, $\operatorname{dock} 1^{\text {stli35 }}$ and $\operatorname{dock} 1^{\text {stl366 }}$, which were generated by TALENs. The TALEN targeter tool (https://tale-nt.cac.cornell.edu/) and GoldyTALEN kit [31] were utilized to build each TALEN in a pCS2+ backbone. The repeat variable domains chosen for each stl365 TALEN arm and stl366 TALEN arm were: stl365 left arm: NN HD NG HD NI HD HD NG NN NI HD NN HD NI NN NI NN NI NN NI; stl365 right arm: HD NG NG NG NN NI NN NG NG NN NI HD HD HD NG NN NI NN NG; stl366 left arm: NN NG NG NI NG NI NG NG HD NI NG HD NG NN NI NI NN NN NI NN; stl366 right arm: NN HD NG NG NI NI NI HD NI NG NI HD NG NN NI HD HD HD NN HD. The TALEN constructs were transcribed with the mMESSAGE mMACHINE SP6 ULTRA Kit (Ambion) and equal concentrations $(\sim 50 \mathrm{pg})$ of left and right arm mRNA were injected into 1-cell stage wild-type embryos. Lesions that were successfully transmitted to the F0 germline were identified by restriction enzyme digest analysis as described above. Mutant bands were gel extracted using a QIAquick Gel Extraction kit (Qiagen) and then Sanger sequenced to identify the lesion.

\section{Posterior lateral line nerve (PLLn) dissection and RNA isolation}

Posterior lateral line nerves (PLLn) were dissected from 6-month-old adult zebrafish. Animals were euthanized in ice water until gill motion ceased for $5 \mathrm{~min}$, followed by transection of the hindbrain. Using angled forceps, the skin was pulled back from behind the operculum on both sides of the animal to expose the PLLn. Small spring-loaded dissection scissors were used to cut the PLLn near the operculum and then forceps were used to gently remove the nerve by slowly pulling the nerve toward the anterior of the fish. Both nerves were transferred to microcentrifuge tubes sitting on dry ice and then flash frozen in liquid nitrogen and stored at $-80{ }^{\circ} \mathrm{C}$. To isolate RNA, 40 nerves were pooled from 20 different 6-month-old adult zebrafish and total RNA was obtained using standard TRIzol (Life Technologies) RNA extraction, with the exception of the homogenization method. Nerves were pooled into a total of $500 \mu \mathrm{l}$ TRIzol and then thoroughly homogenized following these steps in succession: vortexing for $30 \mathrm{~s}$, disruption with a plastic-tipped electric homogenizer for $1 \mathrm{~min}$, and passaged through a syringe and successively smaller needles (22.5 and 27 gauge), 10 times each.

\section{RT-PCR}

To make cDNA, $1 \mu \mathrm{g}$ of total RNA was reverse transcribed using the High Capacity cDNA Reverse Transcription Kit (Applied Biosystems) using random hexamers as per manufacturer instructions. RT-PCR for dock1 was performed on adult PLLn cDNA. The following primers were used: F: 5'-CGGAGTGGCCGTCTACAACTATG-3' (bordering exons 1 and 2) and R: 5'-CAAGCCGGAAACAC ACCCTTC-3' (bordering exons 3 and 4). Milli-Q water was used as a substrate for a control RT-PCR.

\section{Rescue experiment}

Full-length zebrafish dock1 was cloned into pCS2+ using Gibson Assembly. dock1 was amplified in two pieces from zebrafish cDNA using a Phusion mastermix (NEB) and the following primers: part 1: F: 5'-TCTTTTTGCAGGAT CCCATAGAGAAGCGAGAAAAAGTGTG-3' and R: 5'CTCCATGATGATCTGCACGTG-3' and part 2: F: 5'-T CAGCGACATACTGGAGGTGC-3' and R: 5'TAATA CGACTCACTATAGTTGAGGTGTCAGCTGCTTTTCC G-3'. Gibson Assembly was then performed using an in-house Gibson reaction mixture (gifted by the Solnica-Krezel lab, Washington University in St. Louis). Briefly, the fragments were gel extracted and purified using the QIAquick Gel Purification Kit (Qiagen). 30 ng of pCS2 + , linearized with Clal and $\mathrm{Xbal}$, were combined with 5-fold excess of the dock1 PCR fragments and $15 \mu \mathrm{l}$ of the Gibson Assembly enzyme-reagent mixture. The mixture was incubated at $50{ }^{\circ} \mathrm{C}$ for $1 \mathrm{~h}$ and then $10 \mu \mathrm{l}$ were transformed into DH5 alpha cells and plated on ampicillin plates. Subsequent colonies were grown, miniprepped with a Qiagen Kit, and Sanger sequenced. Synthetic mRNA for injection was generated by linearizing dock1 in pCS2+ with Not1 and then transcribing with the mMESSAGE mMACHINE SP6 ULTRA Kit (Ambion). Approximately 120 pg of dock $1 \mathrm{mRNA}$ in $2 \mathrm{nl}$ was injected into 1-cell stage embryos generated from a dock $1^{\text {stl } 145}$ heterozygous in-cross. In situ hybridization for $m b p$ was performed and scoring of expression was performed blinded to genotype.

Whole mount in situ hybridization and qualitative scoring Whole mount in situ hybridization (WISH) was performed as described $[32,33]$ on larvae treated with $0.003 \%$ phenylthiourea from $24 \mathrm{~h}$ post fertilization (hpf) to inhibit pigmentation until fixation in $4 \%$ paraformaldehyde. The previously characterized riboprobes used in this study were: sox10 [34], krox20 [35], and $m b p$ [36]. All phenotypes were scored with the scorer blinded to genotype. The PLLn was scored for strength of staining: "strong" = strong and consistent expression along the entirety of the PLLn; "reduced" = consistent but reduced $m p b$ expression along PLLn; and 
"strongly reduced" = patches of $m b p$ expression or no expression, similar to scoring as performed previously [37]. "Strong" $m b p$ expression was assigned a value of 3, "reduced," a value of 2 , and "strongly reduced," a value of 1 to code each phenotype as a number for a Chi-squared anaylsis.

\section{Transmission Electron microscopy and quantifications}

TEM was performed on $3 \mathrm{dpf}, 5 \mathrm{dpf}$, and $21 \mathrm{dpf}$ cross-sections of the PLLn according to standard protocols [38, 39]. Larvae were cut between body segments 5 and 6 and juvenile $21 \mathrm{dpf}$ fish were cut immediately posterior to the heart. A Jeol JEM-1400 (Jeol USA) electron microscope and AMT V601 digital camera were used to image samples. Quantification of percent myelinated axons, sorted axons, total axon number, and number of Schwann cell nuclei was performed on the entire cross section of the PLLn. The scorer was blinded to genotype, and quantification was performed manually as described previously [37].

\section{Lifeact microinjections and live imaging}

One-cell stage zebrafish embryos were injected with 15-20 ng of sox10:Lifeact-RFP (a gift from the Lyons lab, University of Edinburgh) and $25 \mathrm{ng}$ of transposase mRNA. $1 \mathrm{dpf}$ larvae were then screened for expression of sox10:Lifeact-RFP in Schwann cells at $24 \mathrm{hpf}$. For live-imaging, larvae were anesthetized in Tricaine and embedded in $0.8 \%$ agarose on a $35 \mathrm{~mm}$ glass bottom dish filled with $0.2 \%$ Tricaine and covered with a $22 \times 22 \mathrm{~mm}^{2}$ coverslip on top of vacuum grease [40]. The larvae were then imaged with a Zeiss LSM 880 confocal microscope at $20 \times$ for $3 \mathrm{~h}$ at $3 \mathrm{~min}$ intervals. Still images were captured with a Zeiss LSM 880 II Airyscan FAST confocal microscope at $40 \mathrm{xW}$ with a $1.8 \mathrm{zoom}$. To examine blood vesssls, $4 \mathrm{dpf}$ larvae with $T g(k d l r: m c h e r r y)$ were imaged at $13.5 \times$ with a Nikon SMZ18 fluorescent dissecting microscope.

\section{Eos Photoconversion and quantification of Schwann cell number}

$\operatorname{Tg}(f \circ x d 3: g f p) ; \operatorname{dock} 1^{\text {stll145/+ }}$ fish were crossed to $\operatorname{Tg}(\operatorname{sox} 10(4.9)$ :nls-eos);dock $1^{\text {stl145/+ }}$ fish and offspring were screened for both transgenes at $1 \mathrm{dpf}$. At $2 \mathrm{dpf}$, larvae were placed in $0.8 \%$ low-melt agarose and mounted for imaging as described above. Before counting, larvae were individually exposed to $30 \mathrm{~s}$ of UV light using the DAPI filter with the $20 \times$ objective of a Zeiss LSM 880 confocal microscope. The number of GFP and RFP positive cells along the PLLn spanning $\sim 8$ body segments were the counted manually in ImageJ. The observer was blinded to genotype.

\section{Neuromast labeling and quantification}

$3 \mathrm{dpf}$ larvae derived from a $\operatorname{dock} 1^{\text {stl145 }}$ heterozygous in-cross were incubated with $50 \mu \mathrm{l}$ of DASPEI $(40 \mathrm{mg}$ /
$100 \mathrm{~mL}$ in distilled water) in $4 \mathrm{~mL}$ of egg water for $15 \mathrm{~min}$ at room temperature. The DASPEI solution was removed and replaced with fresh egg water. The number of neuromasts along the PLLn were counted under a fluorescent dissecting microscope using a GFP filter.

\section{Immunohistochemistry}

Immunohistochemistry for acetylated tubulin was performed as described in [32] with mouse anti-acetylated alpha-tubulin used at a dilution of 1:1000 (Sigma). Larvae were fixed at $4 \mathrm{dpf}$ and were derived from a $\operatorname{dock} 1^{\text {stl145 }}$ heterozygous in-cross. Heavy myosin within somites was detected with chicken MF 20 antibody at a dilution of 1:20 (Developmental Studies Hybridoma Bank). MF 20 was deposited to the DSHB by Fischman, D.A. (DSHB Hybridoma Product MF 20). For MF 20 staining, embryos were fixed at $1 \mathrm{dpf}$ in $4 \%$ paraformaldehyde for $1 \mathrm{~h}$ and washed twice with $1 \mathrm{X}$ PBS for $10 \mathrm{~min}$. Samples were then blocked with $0.05 \%$ Triton in PBS and 10\% goat serum and then incubated with MF 20 in block overnight at $4{ }^{\circ} \mathrm{C}$. After incubation, larvae were washed twice with PBS and then incubated secondary antibody in PBS for $2 \mathrm{~h}$ at room temperature. Primary antibodies were detected IgG2b with secondary antibody conjugated to either Alexa 568 or 488 (Invitrogen) at a 1:2000 dilution. Immunostained larvae were imaged with a Nikon SMZ18 fluorescent dissecting microscope.

\section{Statistical analyses}

GraphPad Prism 7 was utilized to perform statistical tests. Unpaired t-tests with Welch's correction were used to test significance of all TEM, neuromast number, and Schwann cell number data. A Chi-squared analysis was utilized to determine significance for all WISH data. Phenotypes of "strong," "reduced," and "strongly reduced" were assigned a number of 3,2 , or 1 , respectively, in order to compare phenotypes with a Chi-squared analysis. An unpaired t-test with Welch's correction showed no significant difference between wild-type and heterozygous animals; therefore, for TEM, WISH, neuromast, and Schwann cell number data, wild-type and heterozygous animals were combined as controls.

\section{Results}

Mutations in dock 1 result in decreased myelin basic protein expression in the peripheral nervous system An $N$-ethyl- $N$-nitrosourea-based forward genetic screen to identify novel genetic regulators of myelination $[29,30]$ uncovered a mutant, allele designation stl145, that exhibits reduced $m b p$ expression in the PNS by whole mount in situ hybridization (WISH). Reduction of $m b p$ expression, scored qualitatively in the posterior lateral line nerve (PLLn) (Additional file 1: Figure S1), is most striking at 3 days post fertilization (dpf) (Fig. 1a, b), during early 

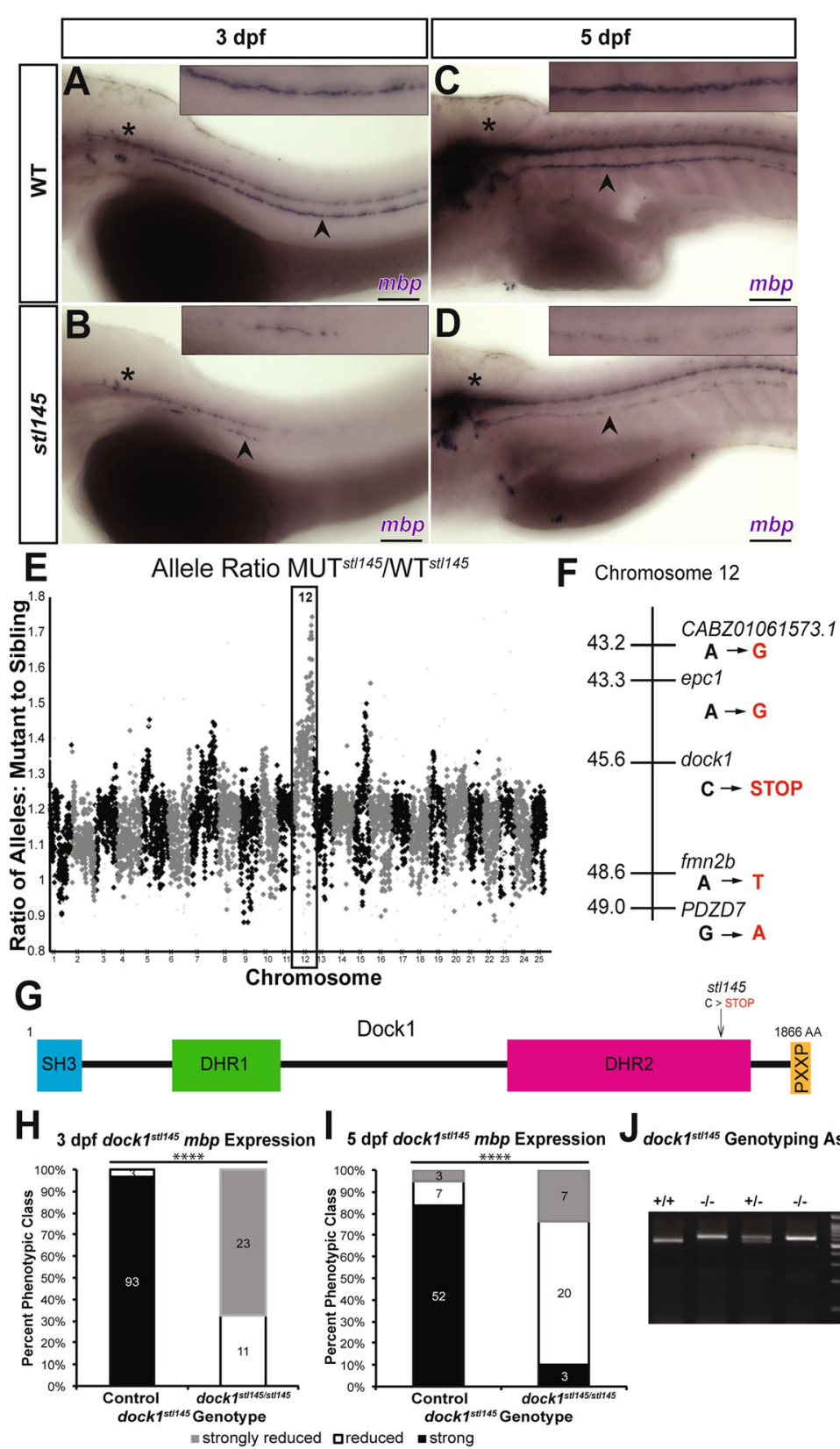

dock $1^{\text {st1 } 145}$ Genotyping Assay

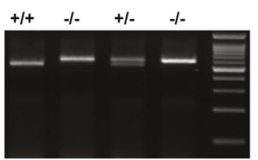

Fig. 1 st/145 mutants exhibit decreased mbp expression in the PNS. a-d) Lateral views of mbp expression by WISH. Arrowheads indicate the PLLn. Asterisks indicate the central nervous system (CNS). Inset panels show a magnified view of the PLLn. Scale bars $=100 \mu m$. a) $m b p$ at 3 dpf is strongly expressed in the PLLn of control larva $(n=93 / 96)$. b) st/145 mutants at 3dpf exhibit reduced $m b p$ expression in the PLLn $(n=34)$. c) $m b p$ expression is strongly expressed in the PLLn of control larva at $5 \mathrm{dpf}(n=52 / 62)$. d) st/145 mutants at $5 \mathrm{dpf}$ express mbp, but at reduced levels compared to control siblings ( $n=27 / 30$ ). e) Analysis of whole genome sequencing data showed that chromosome 12 exhibited the highest mutant to wild-type allele ratio. f) Within the most highly linked region of chromosome 12 , dock 1 was the only gene that contained an early stop codon. $\mathbf{g}$ ) A schematic of the protein structure of Dock1 and the location of the st/145 lesion. The SH3 and proline rich domains can bind adaptor proteins. The DHR-1 domain interacts with Ptdlns $(3,4,5) P_{3}$ and the DHR-2 domain is the catalytic domain can that catalyzes the exchange of GDP for GTP in Rac1. $\left.\mathbf{h}-\mathbf{i}\right)$ Quantification of WISH for mbp at $3 \mathrm{dpf}$ (h) and $5 \mathrm{dpf}$ (i), respectively, based on phenotypic classes and genotypes for the st/145 lesion. ${ }^{* * * *} p<0.0001$, Chi-squared analysis. j) Genotyping assay for the st/145 lesion. The PCR amplified product is digested with BstN1 and run on a 3\% agarose gel

stages of PNS myelination. At $5 \mathrm{dpf}, m b p$ expression has increased in the stl145 mutant PLLn, but is still reduced compared to sibling controls (Fig. 1c, d). To identify the causative mutation, we employed whole genome sequencing
(WGS) of DNA pools from phenotypically mutant and phenotypically wild-type siblings. Analysis of WGS data [30] showed the causative mutation was located on chromosome 12 (Fig. 1e). Within the most highly linked region of 
chromosome 12, the most likely causative mutation was a C-to-T transition resulting in a premature stop codon within the Rac1 binding domain (DHR2 domain) encoding region of dock1 (Fig. 1f, g). Genotyping revealed that dock1 $1^{\text {stll45/ }}$ stl145 homozygous mutations corresponded to decreased levels of $m b p$ expression in the PNS at $3 \mathrm{dpf}(p<0.0001)$ and at $5 \mathrm{dpf}(\mathrm{p}<0.0001)$ (Fig. 1h-j). To definitively demonstrate that this premature stop codon was causative for the stl145 phenotype, we performed a rescue experiment with wild-type dock1 synthetic mRNA. Injection of $120 \mathrm{pg}$ of full-length synthetic dock1 mRNA into 1-cell stage embryos derived from an intercross of dock $1^{\text {stll }} 45$ heterozygotes suppressed the $m b p$ phenotype in $s t l 145$ mutants at $3 \mathrm{dpf}$ $(p=0.0001)$ (Fig. 2 a-e). Additionally, we generated two new alleles of dock1 using TALENs. The stl365 allele generates a premature stop codon in the DHR2 domain, similar to the stl145 allele (Fig. 2 f; Additional file 2: Figure S2 A,B). The stl366 allele causes a premature stop codon generated just after the SH3 domain (Fig. 2 f; Additional file 2: Figure S2 $\mathrm{C}, \mathrm{D})$. Both alleles exhibit decreased $m b p$ expression in the PNS $(p<0.0001)$ and fail to complement with the stl145 allele $\left(\right.$ dock $1^{\text {stl 145/stl365 }}=4 / 4$, dock $1^{\text {stl145/stl365 }}=6 / 6$; Fig. $\left.2 \mathrm{~g}-1\right)$. To confirm that dock1 is expressed in Schwann cells of zebrafish in addition to mammalian Schwann cells [20], RT-PCR for dock1 was performed on cDNA from adult PLLn, which is enriched in Schwann cell nuclei. This analysis showed that dock1 is expressed in the PLLn (Additional file 2: Figure S2 E,F). Together, these results confirm that the stl145 phenotype is the result of the premature stop codon in dock1. The phenotype of these new mutants suggests a previously unappreciated role of Dock1 in Schwann cell development.

\section{Schwann cell myelination is significantly reduced in dock $1^{\text {stl145 }}$ mutants at early stages}

We next investigated which stages of Schwann cell development are affected in $\operatorname{dock} 1^{\text {stll45 }}$ mutants. To interrogate if the decrease of $m b p$ expression in dock $1^{\text {stll45 }}$ mutants is the result of decreased myelination, we employed TEM to analyze the ultrastructure of the PLLn at $3 \mathrm{dpf}$ and $5 \mathrm{dpf}$. At $3 \mathrm{dpf}$, consistent with WISH for $m b p$, the percentage of myelinated axons in the PLLn of $d o c k 1^{\text {stl } 145}$ mutants is significantly reduced compared to siblings $(p<0.0001)$, while the number of axons is not significantly altered $(p=0.0983)$ (Fig. 3a-d). At $5 \mathrm{dpf}$, dock1 $1^{\text {stll145/stll45 }} \mathrm{mu}-$ tant axon number is similarly unaffected $(p=0.3031)$ while mutants did exhibit a significant decrease in the percentage of myelinated axons compared to controls $(p=0.0003)$, although this phenotype is more variable compared to the mutant phenotype at $3 \mathrm{dpf}$ (Fig. 3 e-h). dock $1^{\text {stll145/+ }}$ larvae do not exhibit decreased myelination compared to wild-type siblings at $3 \mathrm{dpf}$ $(p=0.6549$ percent myelinated axons; $p=0.7258$ total axon number) or $5 \mathrm{dpf}$ ( $p=0.7297$ percent myelinated axons; $p=0.6924$ total axon number); thus, wild-type and heterozygous siblings were combined as controls. The presence of

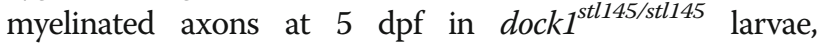
although fewer in number compared to controls, illustrates that Schwann cells do possess the capability to myelinate axons in dock1 mutants. Maternal zygotic (MZ) dock $1^{\text {stl145 }}$ mutants at $5 \mathrm{dpf}$ also exhibit a reduction in the number of myelinated axons compared to MZ dock $1^{\text {stll45 }}$ heterozygotes $(p=0.0183)$ (Additional file 3: Fig. S3 a-d). No significant difference in the percent myelinated axons was observed between zygotic dock $1^{\text {stll45 }}$ mutants and MZ $\operatorname{dock} 1^{\text {stll45 }}$ mutants $(p=0.8300)$. To test if a defect in myelination is consistent between alleles, we performed TEM on $\operatorname{dock} 1^{\text {stl366 }}$ mutants and siblings. These mutants also display a significantly decreased percentage of myelinated axons at $3 \mathrm{dpf}(p=0.0072)$ with no significant difference in axon number $(p=0.3775)$ (Additional file 3: Figure S3 E-H). A slight reduction in the percent myelinated axons of the PLLn persists at $21 \mathrm{dpf}$ in MZ dock $1^{\text {stll45 }}$ mutants $(p=0.0155)$, while axon number $(p=0.5831)$ and Schwann cell nuclei number $(p=0.1583)$ are not significantly altered compared to MZ dock $1^{\text {stll45 }}$ heterozygous controls (Additional file 4: Figure S4). These results show that dock1 mutations lead to reductions in the number of myelinated axons, and that these effects are more pronounced at early stages of development.

\section{Neither Schwann cell migration nor number are affected in $\operatorname{dock} 1^{\text {st } 145}$ mutants}

To understand why myelination is decreased in $\operatorname{dock} 1^{\text {stl } 145}$ mutants at $3 \mathrm{dpf}$, we examined earlier stages of Schwann cell development, beginning with SCPs. Importantly, global development of dock $1^{\text {stll45 }}$ mutants is normal and overt PLLn defects are not observed (Additional file 5: Figure S5 A-F). Acetylated tubulin staining shows that axons extend down the trunk of larvae and neuromast number is not significantly altered $(p=0.7518)$, (Additional file 5: Figure S5 G-I). dock $1^{\text {stl145/+ }}$ larvae and wild-type siblings do not exhibit a significant difference in neuromast number $(p=0.0727)$ and were thus combined as a control. Additionally, blood vessels (kdlr:mcherry positive) and somites (MF 20 positive) can develop in zygotic dock $1^{\text {stll45 }}$ mutants (Additional file 5: Figure S5 J-M). Previous studies have demonstrated that Dock1 can regulate cell migration [41], and two other members of the Dock family of GEFs, Dock7 [20] and Dock8 [21] affect Schwann cell migration. Therefore, we examined if cell migration in $\operatorname{dock}^{\text {stll145 }}$ mutants is perturbed by performing WISH for sox10, which marks all stages of Schwann cell development, including SCPs. At 2 dpf, SCPs have migrated and populated the PLLn in control larvae as evidenced by strong and consistent expression of sox10 along the entire length of the PLLn (Fig. $4 \mathrm{a}$ ). We found that 


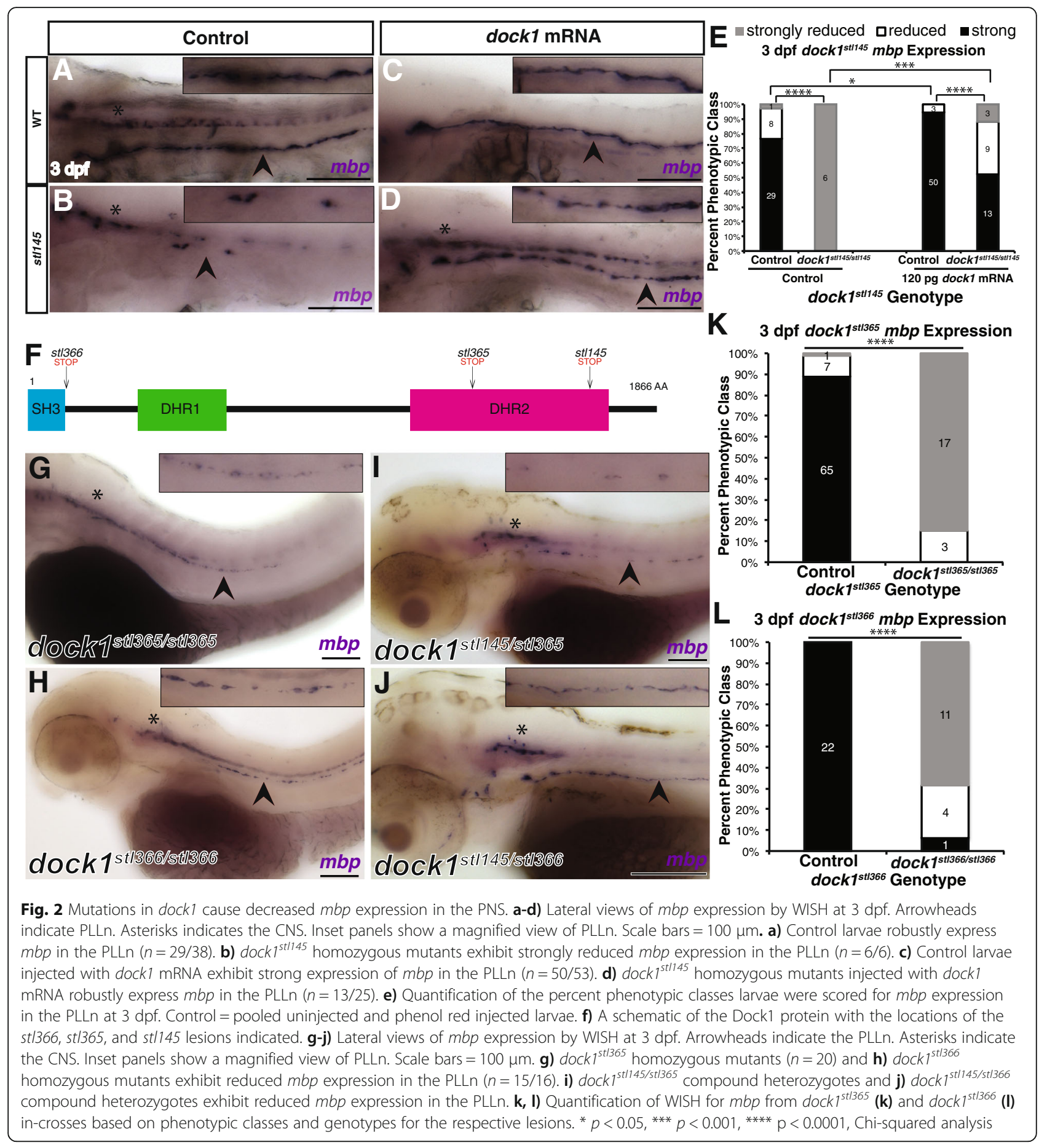

dock $1^{\text {stl145/stll45 }}$ mutants also exhibit consistent and strong expression of sox 10 along the PLLn $(p=0.3522)$, demonstrating that SCP migration is not impaired and that Schwann cells populating the PLLn are thus poised to myelinate (Fig. 4b, c). Dock1 has been shown to regulate the actin cytoskeleton in other systems; therefore, we hypothesized that actin cytoskeletal dynamics might be altered during SCP migration in dock $1^{\text {stll45 }}$ mutants. We performed live-imaging of the PLLn in $\operatorname{tg}(f \circ x d 3: g f p)$; dock $1^{\text {stl } 145}$ wild-type, heterozygous, or mutant larvae that also mosaically expressed sox10:Lifeact-RFP, which binds and fluorescently labels F-actin in cells expressing sox 10 [42]. Live-imaging from $\sim 30-33 \mathrm{hpf}$ did not reveal any overt defects in migration or in actin cytoskeleton localization (Fig. 4d-k; Additional file 6: Movie S1, Additional file 7: Movie S2, Additional file 8: Movie S3 

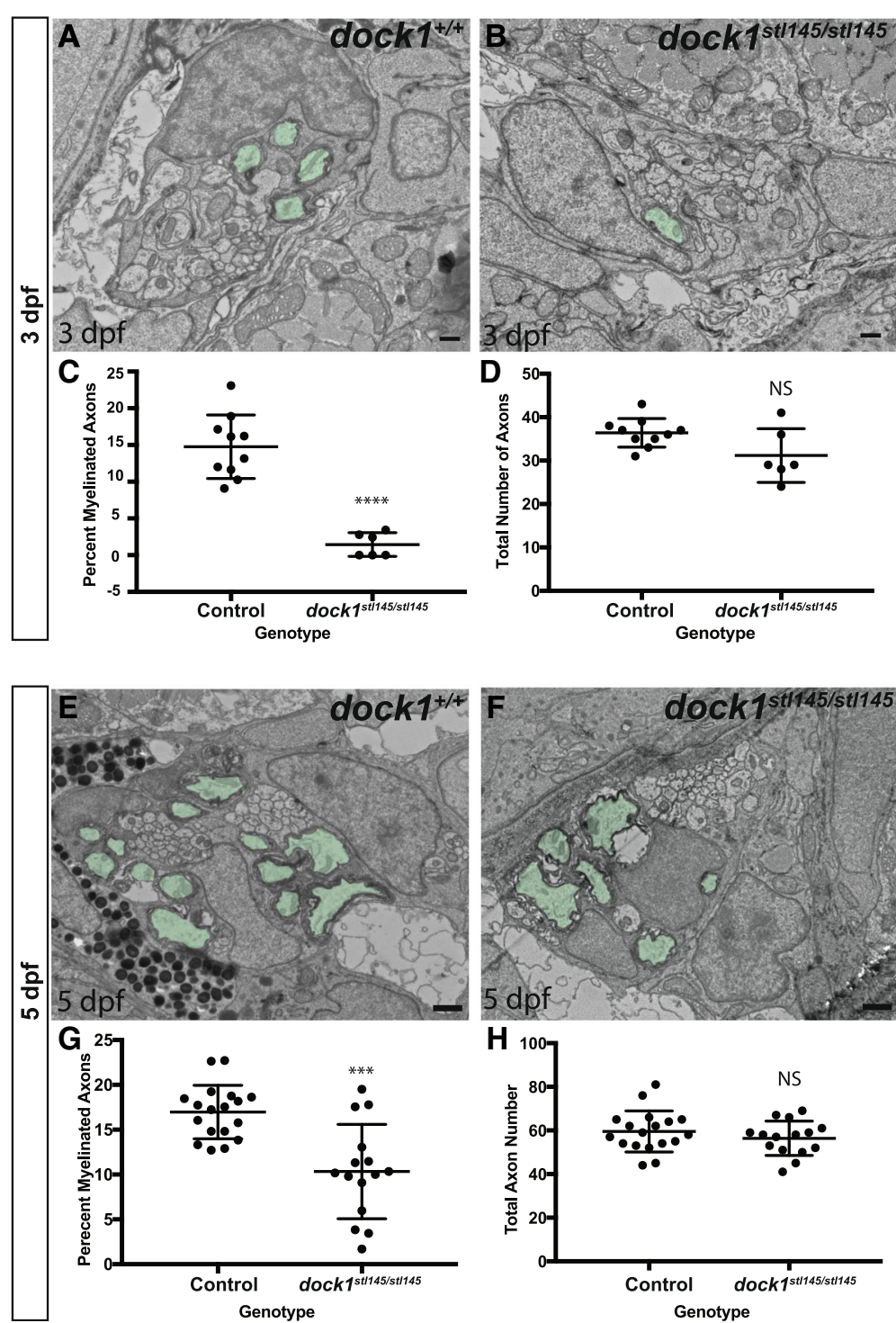

Fig. 3 PNS myelination is significantly reduced in st/145 mutants. a, b) TEM of a cross-section of the PLLn at 3 dpf. Myelinated axons are pseudocolored in green. Scale bars $=500 \mathrm{~nm}$. a) Axons in wild-type PLLn begin to be myelinated while b) dock $7^{\text {st/ } 145}$ homozygous mutant PLLn exhibits fewer myelination of axons. c) Quantification of the percent myelinated axons shows a significant difference between control ( $n=6$ animals, 10 nerves) and dock $7^{5 t / 145}$ mutants $(n=4$ animals, 6 nerves). d) Quantification of the total number of axons (NS, $p=0.0983$ ). e, $\mathbf{f}$ ) Quantification of a cross-section of the PLLn at 5 dpf. Myelinated axons are pseudocolored in green. Scale bars $=500 \mathrm{~nm}$. e) The PLLn of a wild-type larva contains numerous myelinated axons whereas $\mathbf{f}$ ) a dock ${ }^{\text {st/145 }}$ homozygous mutant PLLn contains fewer myelinated axons. g) Quantification of the percent myelinated axons shows a significant difference between control ( $n=11$ animals, 18 nerves) and dock ${ }^{\text {stl } 145}$ mutants ( $n=9$ animals, 15 nerves). h) Quantification of the total number of axons (NS, $\left.p=0.3031\right)$. Bars represent means \pm SD. ${ }^{* * *} p<0.001,{ }^{* * *} p<0.0001$, unpaired $t$ Test with Welch's correction

and Additional file 9: Movie S4). In both control and dock $1^{\text {stll45 }}$ mutant larvae, F-actin was consistently localized to the back of migrating SCPs. To our knowledge, this is the first time live actin dynamics have been reported in migrating SCPs in vivo. High-resolution still images also show LifeAct distributed throughout the cell with the highest concentration at the back of SCPs (Additional file 10: Figure S6).

Because migration is not affected in $\operatorname{dock}^{\text {stll45 }}$ mutants, we examined whether decreased myelination in dock $1^{\text {stl } 45}$ mutant nerves was the result of fewer Schwann cells. To do this, we generated and analyzed $2 \mathrm{dpf}$ double transgenic $\operatorname{tg}(f o x d 3: g f p) ; \operatorname{tg}(\operatorname{sox} 10: n l s-e o s) ;$ dock $1^{\text {stll45 }}$ larvae. The sox10:nls-eos transgene enabled manual counting of Schwann cell nuclei along the PLLn, while the foxd3:gfp transgene provided a co-label to ensure Schwann cell identity. Counting the number of double positive cells at 2 dpf showed that dock $1^{\text {stl } 145 /+}$ and wild-type siblings do not exhibit a significant difference in cell number $(p=0.2218)$ and were thus combined as the control group. No 

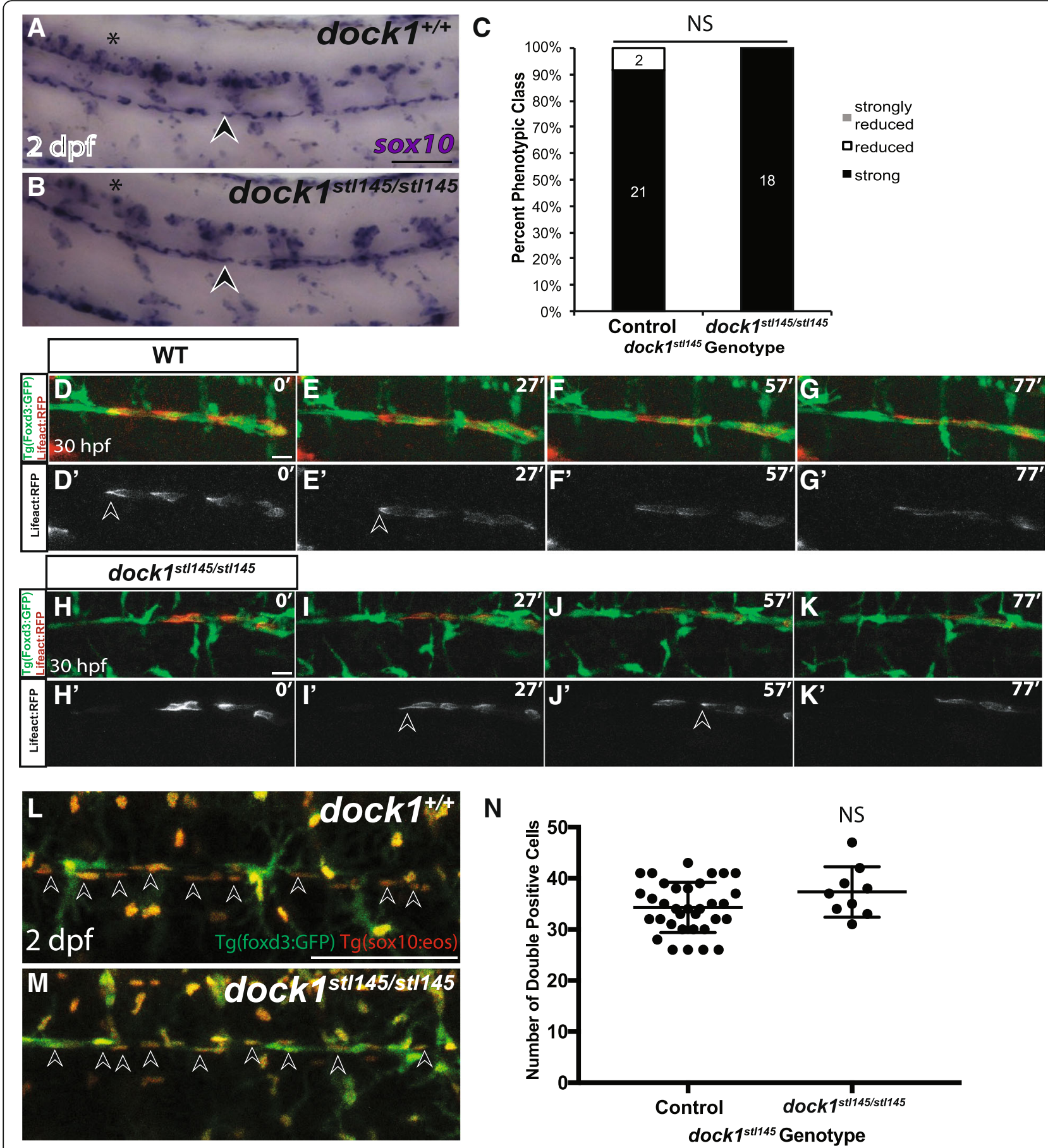

Fig. 4 (See legend on next page.) 
(See figure on previous page.)

Fig. 4 Schwann cell migration and number is not affected in st/145 mutants. a, b) Lateral view of WISH for sox10 at 2 dpf. Arrowheads indicate the PLLn. Asterisks indicate the CNS. a) Strongly expressing sox10 positive cells are located throughout the PLLn in control larvae ( $n=21 / 23)$, similar to $\mathbf{b})$ dock $1^{\text {st/ } / 45}$ homozygous mutant larva $(n=18)$. c) Quantification of WISH for sox 10 at $2 \mathrm{dpf}$ based on phenotypic classes and genotypes for the st/145 lesion shows no significant difference in expression ( $p=0.3522$, Bars represent means \pm SD; Chi-squared analysis). $\mathbf{d}, \mathbf{g}^{\prime}$ ) Still images from time-lapse imaging from 30 to $31.5 \mathrm{hpf}$ in $\mathrm{Tg}$ (foxd3:gfp) wild-type larvae injected with sox10:Lifeact-RFP. Prime panels show Lifeact-RFP strongly localized at the back of migrating Schwann cells (arrowheads). Scale bars $=20 \mu \mathrm{m}$. $\mathbf{h}$-k') Still images from time-lapse imaging

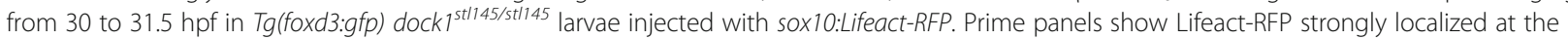
back of migrating Schwann cells (arrowheads). I, m) Lateral view of PLLn in 2 dpf larvae containing $T g(f o x d 3: g f p)$ and $T g(s o x 10(4.9): n / s-e o s)$. Arrows point to examples of double positive Schwann cells. Counting the number of Schwann cells double positive for GFP and RFP in I) control $(n=34)$ and $\mathbf{m})$ dock $1^{\text {st/ } / 45}$ homozygous mutants $(n=9)$. Scale bars $=100 \mu \mathrm{m}$. $\mathbf{n}$ ) Quantification of the number of Schwann cells within a defined region of the PLLn revealed no significant difference in Schwann cell number (NS, $p=0.1360$ ). Bars represent means \pm SD; unpaired $t$ Test with Welch's correction

significant difference in the number of Schwann cells between mutants and control siblings was observed $(p=0.1243)$, suggesting that a reduction in Schwann cell number is not a contributing factor to decreased myelination of the PNS in dock $1^{\text {stllus }}$ mutants (Fig. 4 l-n). Overall, these experiments demonstrate that SCP migration and number are not overtly affected in dock $1^{\text {stl145 }}$ mutants.

\section{Defects in Schwann cell development are first observed during radial sorting and myelination initiation}

Given that the dock $1^{\text {stl } 145}$ mutation does not alter SCP migration, we next asked if Schwann cell development was affected at the immature and pro-myelinating Schwann cell stages using TEM. At $60 \mathrm{hpf}$, Schwann cells in MZ dock $1^{\text {stl145 }}$ heterozygous siblings have begun to myelinate axons whereas MZ dock $1^{\text {stll45 }}$ mutants are extending processes into axon bundles and can be found in the promyelinating, but not myelinating state (Fig. 5 a-c'). This phenotype suggests that radial sorting by Schwann cells is delayed in in dock $1^{\text {stll145 }}$ mutants. We then hypothesized that radial sorting delays at $3 \mathrm{dpf}$ in dock $1^{\text {stll145 }}$ mutants might result in higher numbers of Schwann cells associated with axons in a 1:1 ratio at $5 \mathrm{dpf}$ as more Schwann cells have entered the pro-myelinating state. Indeed, compared to $3 \mathrm{dpf}$, a greater number of Schwann cells are associated in a 1:1 ratio with axons in $d o c k 1^{\text {stll145 }}$ mutants ( $3 \mathrm{dpf}: p=0.6068$; 5dpf: $p=0.0086$ ) (Fig. $5 \mathrm{~d}-\mathrm{i}$ ). To further test if Schwann cells are developmentally delayed at the pro-myelinating state, we examined expression of krox 20 (egr 2 ), a transcription factor that initiates expression of myelin associated genes. By WISH, krox20 expression is significantly decreased along the PLLn of dock $1^{\text {stll45/stll145 }}$ mutants compared to wild-type and heterozygous control siblings at $3 \mathrm{dpf}(p<0.0001)$, demonstrating that $\operatorname{dock} 1^{\text {stll45 }} \mathrm{mu}$ tant Schwann cells are developmentally delayed compared to their siblings (Fig. $5 \mathrm{j}-\mathrm{l}$ ). This reduction in krox 20 expression is not a result of an absence of Schwann cells because sox10 positive Schwann cells are present along the PLLn by WISH at $3 \mathrm{dpf}(p=0.8141)$ (Fig. $5 \mathrm{~m}-\mathrm{o})$. Together, these data show that dock $1^{\text {stl } 145}$ mutants exhibit delays in development that begin during radial sorting and extend throughout initial myelination of the PNS in zebrafish.

\section{Discussion}

A critical component of Schwann cell development is the remodeling of the cytoskeleton to promote shape changes to facilitate proper myelination of the PNS [3, 43]. Although some of the intracellular components involved in cytoskeletal rearrangements have been identified, such as Rac1, the full complement of proteins involved in this process has not been comprehensively defined. Through a forward genetic screen in zebrafish, we identified an early stop codon in the Rac1 binding domain of dock1, an atypical GEF, that causes decreased $m b p$ expression in the PNS at $3 \mathrm{dpf}$ and $5 \mathrm{dpf}$. Rescue experiments and complementation tests with two newly engineered alleles of dock 1 confirmed that mutations in dock1 result in decreased mbp expression.

TEM analysis showed fewer myelinated axons in mutants at $3 \mathrm{dpf}, 5 \mathrm{dpf}$, and $21 \mathrm{dpf}$, whereas axon number is not significantly affected at any stage assessed. However, we did note that several unmyelinated axons in some mutant nerves were abnormally large in diameter and had many mitochondria (data not shown). We demonstrated that reduced $m b p$ expression and the reduction of myelinated axons in mutants is not caused by absence or loss of Schwann cell number. While two other members of the Dock1-family of atypical GEFs, Dock7 and Dock8, affect SCP migration in mammals [20, 21], this does not appear to be the case of Dock1 in zebrafish. This is not entirely unexpected, since loss of Rac1 in mouse Schwann cells did not affect Schwann cell migration [5, 6]. Although overt defects in migration were not detected using live-imaging, these experiments enabled visualization of F-actin localization, which showed that F-actin is localized at the back of migrating Schwann cells. This live-imaging data with Lifeact supports previously reported data from 


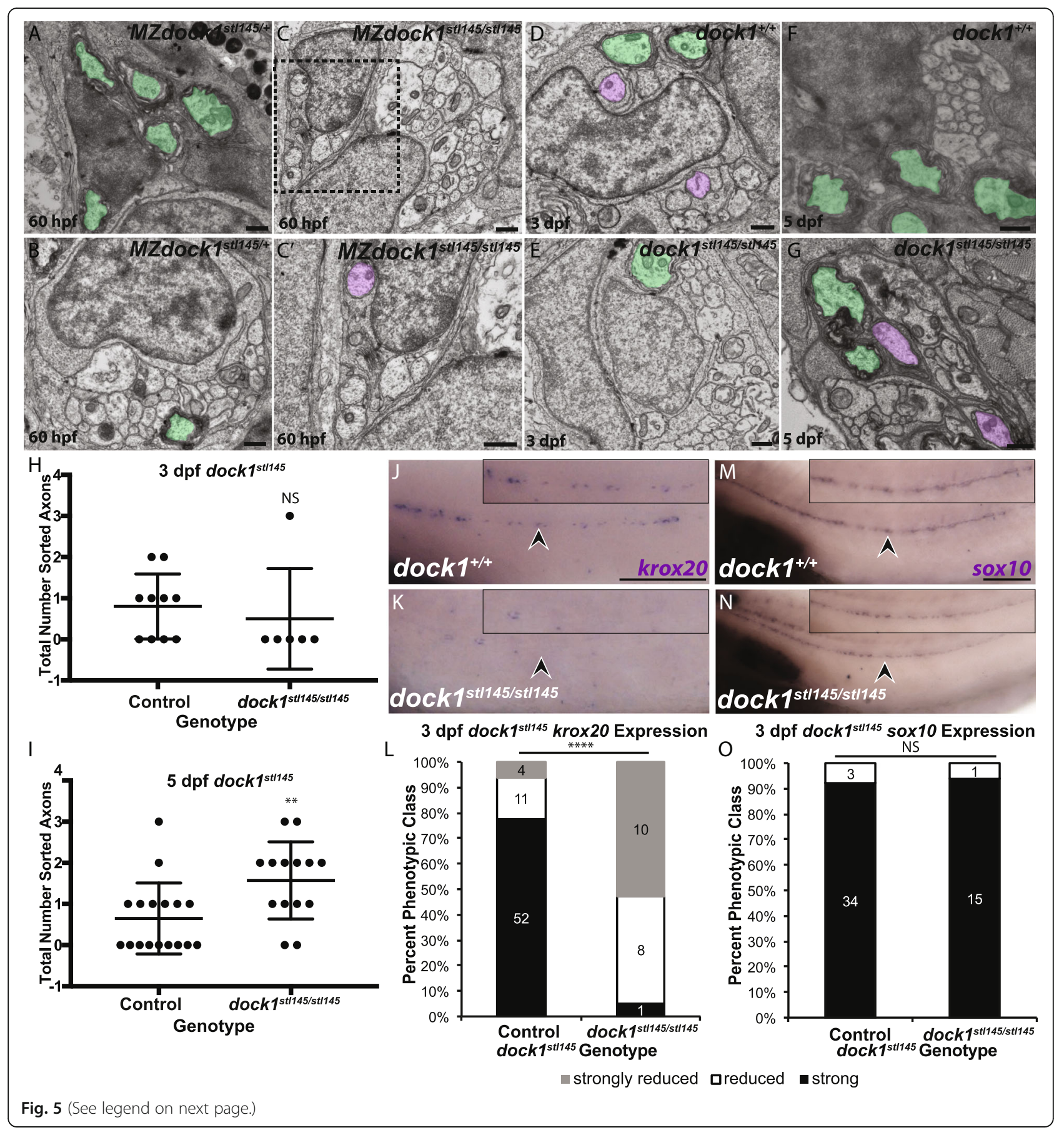


(See figure on previous page.)

Fig. 5 st/145 mutants exhibit delays in radial sorting and decreased expression of krox20. a-g) TEM of cross-sections of the PLLn. Myelinated axons are pseudocolored in green and axons associated with promyelinating Schwann cells are pseudocolored in purple. Scale bars $=500 \mathrm{~nm}$. $\mathbf{a}$, b) Micrographs from the same PLLn within a MZdock $1^{\text {st/145 }}$ heterozygote show Schwann cells myelinating axons at 60 hpf. C) An MZdock $1^{\text {st/145 }}$ homozygous larva does not have myelinated axons at 60 hpf, but Schwann cells are extending processes into axon bundles. (') Magnification of inset from $\mathbf{C}$ shows an axon surrounded by a pro-myelinating Schwann cell. d, e) Schwann cells can myelinate and sort axons at 3 dpf in wildtype ( $n=6$ animals, 10 nerves) and mutant larvae ( $n=4$ animals, 6 nerves). $\mathbf{f}, \mathbf{g})$ More sorted axons are present in mutants $(n=8$ animals, 15 nerves) at $5 \mathrm{dpf}$ compared to controls ( $n=11$ animals, 17 nerves). Quantification of the number of sorted axons at h) $3 \mathrm{dpf}$ and i) $5 \mathrm{dpf}$ shows a statistical difference at $5 \mathrm{dpf}$ (unpaired $t$ Test with Welch's correction). j, k) Lateral view of WISH for krox20 at 3 dpf. Arrowheads indicate PLLn. Inset panels show a magnified view of the PLLn. Scale bar $=50 \mu \mathrm{m}$. j) krox20 is expressed along the PLLn of control larvae $(n=67)$ whereas $\mathbf{k})$ dock $1^{\text {stl } 145}$ homozygous mutants express little to no krox20 along the PLLn $(n=18 / 19)$. I) Quantification of WISH for krox20 at 3 dpf based on phenotypic classes and genotypes for the st/145 lesion ( $p<0.0001$, Chi-squared analysis). $\mathbf{m}, \mathbf{n}$ ) Lateral view of WISH for sox10 at 3 dpf. Arrowheads indicate the PLLn. Inset panels show a magnified view of the PLLn. Scale bar $=50 \mu \mathrm{m}$. $\mathbf{m}$ ) Control larvae exhibit sox10 positive Schwann cells along the PLLn $(n=37)$ similar to $\mathbf{N})$ dock $1^{\text {stl } 145}$ homozygous mutants $(n=16)$. o) Quantification of WISH for sox 10 at $3 \mathrm{dpf}$ based on phenotypic classes and genotypes for the st/145 lesion ( $p=0.8141$, Chi-squared analysis). Bars represent means $\pm \mathrm{SD}^{* *} p<0.001$,

$* * * * 0.0001$

3D culture of Schwann cells showing that migrating Schwann cells in vivo move in an amoeboid-like fashion [44], as contractions seem to occur at the back of the cell. In the future, it will be interesting to generate $\operatorname{dock} 7$ and dock8 zebrafish genetic mutants and observe how migration and F-actin localization is affected in SCPs.

Although a significant reduction in the percent myelinated axons is observed at $5 \mathrm{dpf}$, Schwann cells in dock $1^{\text {stll45 }}$ mutants do have the capability to myelinate axons, suggesting that dock 1 is involved in the timing of myelination onset. It is also possible that other Dock1 family members compensate for dock 1 loss of function in our mutants. Further experiments are needed to determine if Dock1 functions in a Schwann cell-autonomous or non-cell-autonomous manner. Consistent with data showing that dock1 mutant Schwann cells are delayed in radial sorting and myelination, expression of krox 20 , a transcription factor essential for expression of myelin genes, is decreased in $\operatorname{dock} 1^{\text {stll145 }}$ mutant nerves. Importantly, Schwann cell number is not affected in dock $1^{\text {stll145 }}$ mutants and overall PLLn development is not affected in dock $1^{\text {stl }}{ }^{145}$ mutants compared to controls, as determined by acetylated tubulin staining and counting neuromast number. Combined, these data demonstrate that Schwann cell radial sorting and myelination are delayed in dock1 mutants.

How might Dock1 regulate Schwann cell radial sorting and myelination? GEFs are proposed to aid in regulating the spatial and temporal activation of RhoGTPases, such as Rac1 [8]. During the course of development, Schwann cells undergo unique and critical cell shape changes during migration, radial sorting, and myelination. We hypothesize that to regulate the cytoskeletal rearrangements necessary for such functions, Schwann cells utilize a "tool-kit" of GEFs - both canonical and atypical - to activate RhoGTPases, which subsequently remodel the cytoskeleton. For example, Dock7 and Dock8, in addition to canonical GEFs, Dbl's big sister (Dbs) [10] and Tiam1 [9], have already been shown to regulate SCP migration. Dock1 may be activated after Schwann cells have migrated to subsequently promote radial sorting and early myelination. Because few GEFs have been 
shown to play a role in Schwann cell development in vivo, important next steps in elucidating the discrete signals necessary for development will be to define the repertoire of active GEFs, particularly after SCP migration (Fig. 6). RhoGTPases, like Rac1, are ubiquitous and important for initiating cytoskeletal rearrangements as well as other cell biological processes; therefore, different GEFs may be utilized to activate RhoGTPases cell-specifically. Previously, it has been shown that Rac1 activation regulates Schwann cell radial sorting and myelination [6] in addition to promoting the transition from Schwann cell migration to radial sorting [5]. Because Dock1 has been shown to specifically bind and activate Rac1 in various biological contexts, we hypothesize that if Dock1 functions cell-autonomously, it may be one of many GEFs that activate Rac1 in Schwann cells. Multiple GEFs working together in concert could increase the total levels of activated Rac1 during a critical period in Schwann cell development to enable the process extensions necessary for radial sorting and myelination. One explanation of our data is that Schwann cell radial sorting and myelination is slower in dock1 mutants because activated Rac1 levels have not reached a critical threshold to promote these processes. In the future, as better in vivo Rac1 sensors are developed, it will be interesting to test this hypothesis. Additionally, Dock1 may function redundantly with other GEFs. As radial sorting and myelination are critical for PNS health, many GEFs may converge on the same pathway such that if only one GEF is dysfunctional, radial sorting and myelination can still proceed, albeit at a slower rate. Alternatively, Dock1 may function in neurons and mutations in dock1 may indirectly affect Schwann cell development.

The cell autonomy of Dock1 function and the upstream signals that trigger Dock1 activation remain to be elucidated. Dock1 has a DHR1 domain that can bind phosphatidylinositols [45] located in the cell membrane, making Dock1 is an attractive candidate to serve as a link between cell surfaces receptor and the cytoskeleton. Additionally, Dock1 could be a representative of a class of drug targets for diseases affecting peripheral myelin, especially because GEFs may contribute to myelination disease states in human patients [4, 46-48]. Although RhoGTPases are critical for cytoskeletal rearrangements, their ubiquity in many cell types limits their ability to serve as useful therapeutic drug targets. Alternatively, GEFs, particularly atypical GEFs like Dock1, could open a door to indirectly affect RhoGTPases in a more cell-specific manner and thus influence the cell shape changes that promote proper Schwann cell development and myelination.

\section{Conclusions}

In this study, we demonstrate that mutations in an atypical GEF, dock1, result in defects in Schwann cell radial sorting and myelination. Schwann cells are slower to extend processes into axon bundles and subsequently myelinate fewer axons. Schwann cell number and migration are not affected in these mutants; however, Schwann cells in dock1 mutants fail to robustly express markers such as $m b p$ and krox20 in early development, suggesting that dock1 aids in the temporal regulation of Schwann cell radial sorting and development. Moreover, Dock1 may represent a link between extracellular signals and the intracellular cytoskeletal rearrangements necessary for radial sorting and myelination.

\section{Additional files}

Additional file 1: Figure S1. A-C) Lateral view of WISH for $m b p$

Arrowheads indicate the PLLn. Asterisks indicate the CNS. A)

Representative image of a PLLn scored as "strong" expression, with mbp strongly and continuously expressed along PLLn B) as "reduced" expression, with reduced but consistent mbp expression along PLLn and C) as "strongly reduced" with patchy mbp expression along the PLLn. (PDF 846 kb)

Additional file 2: Figure S2. A) The st/365 allele was generated by a TALEN that resulted in one base pair insertion causing an early stop. B) Genotyping assay for the st/365 lesion. The PCR amplified product is digested with EcoRV and run on a 3\% agarose gel. C) The st/366 allele was generated by a TALEN that resulted in a 13 base-pair deletion causing an early stop. D) Genotyping assay for the st/366 lesion. The PCR amplified product is digested with $\mathrm{HpyCH} 4 \mathrm{II}$ and run on a $3 \%$ agarose gel. E) RT-PCR for dock1 on adult PLLn CDNA shows dock1 is expressed in the PLLn. F) Control reaction performed with Milli-q water as a substrate. (PDF 362 kb)

Additional file 3: Figure S3. A-B) TEM of a cross-section of the PLLn at $5 \mathrm{dpf}$ in $\mathrm{MZ}$ siblings. Myelinated axons are pseudocolored in green. Scale bars $=500 \mathrm{~nm}$. A) Axons in MZdock $1^{\text {st/ } / 45}$ heterozygotes ( $n=4$ animals, 6 nerves) contain many myelinated axons whereas B) MZdock $1^{\text {st/145 }} \mathrm{mu}$ tants have fewer myelinated axons ( $n=5$ animals, 8 nerves). C) Quantification of the percent myelinated axons. D) Quantification of the total number of axons (NS, $p=0.2926$ ). E-F) TEM of a cross-section of the PLLn at $3 \mathrm{dpf}$ in dock $^{\text {st } / 366}$ siblings. Myelinated axons are pseudocolored in green. Scale bars $=500 \mathrm{~nm}$. E) Schwann cells in control siblings have myelinated more axons ( $n=4$ animals, 6 nerves) compared to $F$ ) dock $1^{\text {st/366 }}$ homozygous mutant nerves ( $n=3$ animals, 5 nerves). G) Quantification of the percent myelinated axons. H) Quantification of the total number of axons (NS, $p=0.3775$ ). Bars represent means \pm SD. ${ }^{*} p<0.05$, ${ }^{* *} p<0.01$, unpaired $t$ Test with Welch's correction. (PDF $1677 \mathrm{~kb}$ )

Additional file 4: Figure S4. A-B) TEM of a cross-section of the PLLn at $21 \mathrm{dpf}$ in MZ siblings. Scale bars $=10 \mu \mathrm{m}$. (A'-B') Magnified images. Scale bars $=2 \mu \mathrm{m}$. A-A') Axons in MZdock $1^{\text {st/ } / 45}$ heterozygotes ( $\mathrm{n}=4$ animals, 5 nerves) contain many myelinated axons and $\mathbf{B}^{\left.-B^{\prime}\right)}$ MZdock $1^{\text {st } / 145}$ mutants have fewer myelinated axons ( $n=2$ animals, 3 nerves). C) Quantification of the percent myelinated axons. D) Quantification of the total number of axons (NS, $p=0.5831$ ). E) Quantification of the total number of Schwann cell nuclei (NS, $p=0.1583$ ). Bars represent means \pm SD. ${ }^{*} p<$ 0.05, unpaired $t$ Test with Welch's correction. (PDF $2275 \mathrm{~kb}$ )

Additional file 5: Figure 5. Gross development is normal at $3 \mathrm{dpf}$ comparing A) wild-type, B) heterozygous, and C) mutant larvae from a dock $1^{\text {st/ } / 45}$ intercross. Scale bars $=500 \mu \mathrm{m}$. D-F) Gross development is normal and swim bladders have inflated at $5 \mathrm{dpf}$ comparing D) wild-type, E) heterozygous, and F) mutant from a dock $7^{\text {st } / 145}$ intercross. Scale bars $=500 \mu \mathrm{m}$. G) Acetylated tubulin shows axons are present and well-fasiculated in both wild-type $(n=3)$ and $\mathbf{H})$ dock $1^{\text {st/145/st/145 }}$ mutant lavae $(n=9)$ at $4 \mathrm{dpf}$. I) Neuromast number, detected by 
DASPEI labeling, did not vary between controls $(n=46)$ or mutants $(n=16)$ at 3 $\operatorname{dpf}(N S, p=0.7518)$, indicating that global PLLn development is not affected. Bars represent means \pm SD; unpaired $t$ Test with Welch's correction. J) Tg(kdlr:mcherry) labeling blood vessels at $4 \mathrm{dpf}$ in wild-type and $\mathbf{K}$ ) dock $7^{\text {stl } / 4 / \text { stl }^{2} 45}$ mutants. L) MF 20 staining shows defined somite development in wild-type and $\mathbf{M}$ ) dock $1^{\text {stl/14/ }}$ stl145 mutant lavae at $1 \mathrm{dpf}$. Scale bars $=100 \mu \mathrm{m}$. (PDF $5492 \mathrm{~kb}$ )

Additional file 6: Movie S1. Live-imaging of a $T g(f o x d 3: g f p)$ wild-type larva ( 30-33 hpf) injected with sox10:Lifeact-RFP. The larva was imaged every 3 min for $3 \mathrm{~h}$. (AVl $8176 \mathrm{~kb}$ )

Additional file 7: Movie S2. Grayscale single channel movie of Lifeact as seen in Additional file 6: Movie S1. (AVI $6489 \mathrm{~kb}$ )

Additional file 8: Movie S3. Live-imaging of a Tg(foxd3:gfp) dock ${ }^{\text {stl/45/ }}$ st/145 larva ( 30-33 hpf) injected with sox10:Lifeact-RFP. The larva was imaged every 3 min for 3 h. (AVI $5595 \mathrm{~kb}$ )

Additional file 9: Movie S4. Grayscale single channel movie of Lifeact as seen in Additional file 8: Movie S3. (AVI $2810 \mathrm{~kb}$ )

Additional file 10: Figure S6. A) Zeiss Airyscan image of Tg(foxd3:gfp) wild-type and B) $T g$ (foxd3:gfp) dock $7^{\text {st/145/4 }}$ larva ( $30 \mathrm{hpf}$ ) injected with sox10:Lifeact-RFP. A'-B') Lifeact-RFP localization within Schwann cell precursors. Scale bars $=10 \mu \mathrm{m}$. (PDF $557 \mathrm{~kb}$ )

\section{Abbreviations}

bp: Base pair; CNS: Central nervous system; dpf: Days post fertilization; GDP: Guanosine diphosphate; GEF: Guanine nucleotide exchange factor; GTP: Guanosine triphosphate; hpf: Hours post fertilization; mbp: Myelin basic protein; MF 20: Myosin heavy chain antibody; mm: Millimeter; mM: Millimolar; MZ: Maternal zygotic; ng: Nanogram; nl: Nanoliter; PBS: Phosphate buffered saline; PCR: Polymerase chain reaction; pg: Picogram; PLLn: Posterior lateral line nerve; PNS: Peripheral nervous system;

Ptdlns(3,4,5) $\mathrm{P}_{3}$ : Phosphatidylinositol $(3,4,5)$-trisphosphate; SCP: Schwann cell precursor; SD: Standard deviation; TEM: Transmission electron microscopy; WISH: Whole mount in situ hybridization; WT: Wild-type; $\mu \mathrm{g}$ : Microgram; $\mu \mathrm{m}$ : Micrometer

\section{Acknowledgements}

We thank members of the Monk, Solnica-Krezel, and Kaufman laboratories for assistance with the screen and helpful discussions; the Washington University Center for Cellular Imaging; the Washington University Zebrafish Consortium; S. Kucenas (University of Virginia) for the $\mathrm{Tg}($ sox 10(4.9):n/s-eos) line; D. Lyons for the sox10:lifeact-RFP plasmid; C. Shiau (University of North Carolina) for the Tg(kdlr:mcherry) line; M. Mokallad (Washington University) for the acetylated alpha-tubulin antibody, and the Solnica-Krezel laboratory (Washington University) for the MF 20 antibody.

\section{Author contributions}

A.L.H., B.L.H, S.D.A., and K.R.M. performed the genetic screen and identified the st/145 mutant. R.L.C. and K.R.M designed research, and R.L.C. performed research. R.L.C. and K.R.M analyzed data, and R.L.C. and K.R.M. wrote the paper. All authors edited and approved of the manuscript.

\section{Funding}

R.L.C. is supported by the National Science Foundation Graduate Research Fellowship (DGE-1745038). This work was also supported by the Philip and Sima Needleman Student Fellowship in Regenerative Medicine (A.L.H.) and by the National Institute of Neurological Disorders and Stroke (NINDS) Grants F31 NS096814 (A.L.H), F31 NS094004 (to B.L.H.), and F31 NS087801 (to S.D.A.), and by a National Institute of Child Health and Human Development Grant R01 HD80601 (to K.R.M.). K.R.M. is a Harry Weaver Neuroscience Scholar of the NMSS.

\section{Availability of data and materials}

Data, reagents, and zebrafish lines available on request from the authors.

\section{Ethics approval and consent to participate}

Zebrafish were reared in accordance with the Washington University IRB and animal protocols and were raised in the Washington University Zebrafish Consortium (http://zebrafish.wustl.edu/husbandry.htm).

\section{Consent for publication}

Not applicable.

\section{Competing interests}

The authors have no competing interests.

\section{Publisher's Note}

Springer Nature remains neutral with regard to jurisdictional claims in published maps and institutional affiliations.

\section{Author details}

${ }^{1}$ Department of Developmental Biology, Washington University School of Medicine, St. Louis, MO 63110, USA. ${ }^{2}$ Vollum Institute, Oregon Health and Science University, Portland, OR 97239, USA. Institute of Neuroscience, University of Oregon, Eugene, OR 97403, USA.

\section{Received: 15 May 2018 Accepted: 20 July 2018}

Published online: 08 August 2018

\section{References}

1. Jessen KR, Mirsky R. The origin and development of glial cells in peripheral nerves. Nat Rev Neurosci. 2005;6:671-82.

2. Monk KR, Feltri ML, Taveggia C. New insights on Schwann cell development. Glia. 2015;63:1376-93.

3. Feltri ML, Poitelon Y, Previtali SC. How Schwann cells sort axons: new concepts. Neuroscientist. 2016;22:252-65.

4. Feltri ML, Suter $\mathrm{U}$, Relvas JB. The function of RhoGTPases in axon ensheathment and myelination. Glia. 2008:56:1508-17.

5. Nodari A, Previtali SC, Dati G, Occhi S, Court FA, Colombelli C, et al. Alpha6beta4 integrin and dystroglycan cooperate to stabilize the myelin sheath. J Neurosci. 2008;28:6714-9.

6. Benninger Y, Thurnherr T, Pereira JA, Krause S, Wu X, Chrostek-Grashoff A, et al. Essential and distinct roles for $\mathrm{cdc} 42$ and rac1 in the regulation of Schwann cell biology during peripheral nervous system development. J Cell Biol. 2007;177:1051-61.

7. Guo L, Moon C, Niehaus K, Zheng Y, Ratner N. Rac1 controls Schwann cell myelination through CAMP and NF2/merlin. J Neurosci. 2012;32:17251-61.

8. Rossman KL, Der CJ, Sondek J. GEF means go: turning on RHO GTPases with guanine nucleotide-exchange factors. Nat Rev Mol Cell Biol. 2005;6:167-80.

9. Yamauchi J, Miyamoto Y, Tanoue A, Shooter EM, Chan JR. Ras activation of a Rac1 exchange factor, Tiam1, mediates neurotrophin-3-induced Schwann cell migration. Proc Natl Acad Sci U S A. 2005;102:14889-94.

10. Yamauchi J, Chan JR, Miyamoto Y, Tsujimoto G, Shooter EM. The neurotrophin-3 receptor TrkC directly phosphorylates and activates the nucleotide exchange factor Dbs to enhance Schwann cell migration. Proc Natl Acad Sci U S A. 2005;102:5198-203.

11. Miyamoto Y, Torii T, Nakamura K, Takashima S, Sanbe A, Tanoue A, et al. Signaling through Arf6 guanine-nucleotide exchange factor cytohesin-1 regulates migration in Schwann cells. Cell Signal. 2013;25:1379-87.

12. Yamauchi J, Miyamoto Y, Torii T, Takashima S, Kondo K, Kawahara K, et al. Phosphorylation of cytohesin-1 by Fyn is required for initiation of myelination and the extent of myelination during development. Sci Signal. 2012;5 ra69

13. Brugnera E, Haney L, Grimsley C, Lu M, Walk SF, Tosello-Trampont A-C, et al. Unconventional Rac-GEF activity is mediated through the Dock180-ELMO complex. Nat Cell Biol. 2002;4:574-82.

14. Côté J-F, Vuori K. Identification of an evolutionarily conserved superfamily of DOCK180-related proteins with guanine nucleotide exchange activity. J Cell Sci. 2002;115:4901-13.

15. Côté J-F, Vuori K. GEF what? Dock180 and related proteins help Rac to polarize cells in new ways. Trends Cell Biol. 2007;17:383-93.

16. Hasegawa H, Kiyokawa E, Tanaka S, Nagashima K, Gotoh N, Shibuya M, et al. DOCK180, a major CRK-binding protein, alters cell morphology upon translocation to the cell membrane. Mol Cell Biol. 1996;16:1770-6.

17. Reddien PW, Horvitz HR. CED-2/Crkll and CED-10/Rac control phagocytosis and cell migration in Caenorhabditis elegans. Nat Cell Biol. 2000;2:131-6.

18. Ziegenfuss JS, Doherty J, Freeman MR. Distinct molecular pathways mediate glial activation and engulfment of axonal debris after axotomy. Nat Neurosci. 2012;15:979-87. 
19. Laurin M, Fradet N, Blangy A, Hall A, Vuori K, Côté J-F. The atypical Rac activator Dock180 (Dock1) regulates myoblast fusion in vivo. Proc Natl Acad Sci U S A. 2008;105:15446-51.

20. Yamauchi J, Miyamoto Y, Chan JR, Tanoue A. ErbB2 directly activates the exchange factor Dock7 to promote Schwann cell migration. J Cell Biol. 2008;181:351-65.

21. Miyamoto Y, Torii T, Kawahara K, Tanoue A, Yamauchi J. Dock8 interacts with Nck1 in mediating Schwann cell precursor migration. Biochem Biophys Rep. 2016;6:113-23.

22. Monk KR, Talbot WS. Genetic dissection of myelinated axons in zebrafish. Curr Opin Neurobiol. 2009;19:486-90.

23. Moore CA, Parkin CA, Bidet $Y$, Ingham PW. A role for the myoblast city homologues Dock1 and Dock5 and the adaptor proteins Crk and Crk-like in zebrafish myoblast fusion. Development. 2007;134:3145-53.

24. Epting D, Wendik B, Bennewitz K, Dietz CT, Driever W, Kroll J. The Rac1 regulator ELMO1 controls vascular morphogenesis in zebrafish. Circ Res. 2010;107:45-55.

25. Schäker K, Bartsch S, Patry C, Stoll SJ, Hillebrands J-L, Wieland T, et al. The bipartite rac1 guanine nucleotide exchange factor engulfment and cell motility 1/dedicator of cytokinesis 180 (elmo1/dock180) protects endothelial cells from apoptosis in blood vessel development. J Biol Chem. 2015;290:6408-18.

26. McGraw HF, Snelson CD, Prendergast A, Suli A, Raible DW. Postembryonic neuronal addition in zebrafish dorsal root ganglia is regulated by notch signaling. Neural Dev. 2012;7:23.

27. Gilmour DT, Maischein H-M, Nüsslein-Volhard C. Migration and function of a glial subtype in the vertebrate peripheral nervous system. Neuron. 2002;34:577-88.

28. Wang Y, Kaiser MS, Larson JD, Nasevicius A, Clark KJ, Wadman SA, et al. Moesin 1 and Ve-cadherin are required in endothelial cells during in vivo tubulogenesis. Development. 2010;137:3119-28.

29. Herbert AL, Fu M-M, Drerup CM, Gray RS, Harty BL, Ackerman SD, et al. Dynein/dynactin is necessary for anterograde transport of Mbp mRNA in oligodendrocytes and for myelination in vivo. Proc Natl Acad Sci U S A. 2017;114:E9153-62.

30. Sanchez NE, Harty BL, O'Reilly-Pol T, Ackerman SD, Herbert AL, Holmgren M, et al. Whole Genome Sequencing-Based Mapping and Candidate Identification of Mutations from Fixed Zebrafish Tissue. G3 (Bethesda). 2017; g3.300212.2017

31. Bedell VM, Wang Y, Campbell JM, Poshusta TL, Starker CG, li RGK, et al. In vivo genome editing using a high-efficiency TALEN system. Nature. 2012; 491:114-8.

32. Cunningham RL, Monk KR. Whole mount in situ hybridization and immunohistochemistry for zebrafish larvae. Methods Mol Biol. 2018; 1739:371-84.

33. Thisse C, Thisse B. High-resolution in situ hybridization to whole-mount zebrafish embryos. Nat Protoc. 2008;3:59-69.

34. Dutton KA, Pauliny A, Lopes SS, Elworthy S, Carney TJ, Rauch J, et al. Zebrafish colourless encodes sox10 and specifies non-ectomesenchymal neural crest fates. Development. 2001;128:4113-25.

35. Pogoda H-M, Sternheim N, Lyons DA, Diamond B, Hawkins TA, Woods IG, et al. A genetic screen identifies genes essential for development of myelinated axons in zebrafish. Dev Biol. 2006;298:118-31.

36. Lyons DA, Pogoda H-M, Voas MG, Woods IG, Diamond B, Nix R, et al. erbb3 and erbb2 are essential for schwann cell migration and myelination in zebrafish. Curr Biol. 2005;15:513-24.

37. Petersen SC, Luo R, Liebscher I, Giera S, Jeong S-J, Mogha A, et al. The adhesion GPCR GPR126 has distinct, domain-dependent functions in Schwann cell development mediated by interaction with laminin-211. Neuron. 2015;85:755-69.

38. Cunningham RL, Monk KR. Transmission Electron microscopy for zebrafish larvae and adult lateral line nerve. Methods Mol Biol. 2018;1739:385-400.

39. Czopka T, Lyons DA. Dissecting mechanisms of myelinated axon formation using zebrafish. Methods Cell Biol. 2011;105:25-62.

40. Cunningham RL, Monk KR. Live imaging of Schwann cell development in zebrafish. Methods Mol Biol. 2018;1739:401-5.

41. Grimsley CM, Kinchen JM, Tosello-Trampont A-C, Brugnera E, Haney LB, Lu $\mathrm{M}$, et al. Dock180 and ELMO1 proteins cooperate to promote evolutionarily conserved Rac-dependent cell migration. J Biol Chem. 2004;279:6087-97.

42. Riedl J, Crevenna AH, Kessenbrock K, Yu JH, Neukirchen D, Bista M, et al. Lifeact: a versatile marker to visualize F-actin. Nat Methods. 2008;5:605-7.
43. Salzer JL. Schwann cell myelination. Cold Spring Harb Perspect Biol. 2015;7: a020529.

44. Cattin A-L, Burden JJ, Van Emmenis L, Mackenzie FE, Hoving JJA, Garcia Calavia N, et al. Macrophage-induced blood vessels guide Schwann cellmediated regeneration of peripheral nerves. Cell. 2015;162:1127-39.

45. Côté J-F, Motoyama AB, Bush JA, Vuori K. A novel and evolutionarily conserved Ptdlns $(3,4,5)$ P3-binding domain is necessary for DOCK180 signalling. Nat Cell Biol. 2005;7:797-807.

46. Delague V, Jacquier A, Hamadouche T, Poitelon Y, Baudot C, Boccaccio I, et al. Mutations in FGD4 encoding the rho GDP/GTP exchange factor FRABIN cause autosomal recessive Charcot-Marie-tooth type $4 \mathrm{H}$. Am J Hum Genet. 2007;81:1-16.

47. Stendel C, Roos A, Deconinck T, Pereira J, Castagner F, Niemann A, et al. Peripheral nerve demyelination caused by a mutant rho GTPase guanine nucleotide exchange factor, frabin/FGD4. Am J Hum Genet. 2007;81:158-64.

48. Verhoeven K, De Jonghe P, Van de Putte T, Nelis E, Zwijsen A, Verpoorten N, et al. Slowed conduction and thin myelination of peripheral nerves associated with mutant rho guanine-nucleotide exchange factor 10. Am J Hum Genet. 2003;73:926-32.

\section{Ready to submit your research? Choose BMC and benefit from:}

- fast, convenient online submission

- thorough peer review by experienced researchers in your field

- rapid publication on acceptance

- support for research data, including large and complex data types

- gold Open Access which fosters wider collaboration and increased citations

- maximum visibility for your research: over $100 \mathrm{M}$ website views per year

At BMC, research is always in progress.

Learn more biomedcentral.com/submissions 